\title{
When student-activating teaching conflict with students' desire for efficiency. A communication perspective on undergraduate students' media use
}

\author{
Anne Mette Bjørgen \\ Inland Norway University of Applied Sciences \\ Email: anne.mette.bjorgen@inn.no

\section{Yvonne Fritze} \\ Inland Norway University of Applied Sciences \\ Email: yvonne.fritze@inn.no
}

\section{Abstract}

This article explores how students on a bachelor's course in Media Education understand the educational framework for teaching based on how they choose to participate in the teaching communication. The Norwegian Educational Quality Reform has promoted expectations of student-activating teaching methods to increase the scope of student-active learning. Digital technology was introduced in response to this challenge. Data was gathered through group interviews, a survey, and information from activity logs in the university college's learning platform. The article aims to shed light on what media practices the students consider as important and how their experiences correspond with the teachers' academic use of media. Students seem to prefer to study effectively, at the expense of activating teaching methods and of being active producers of learning. Although students are expected to be digitally competent, it should not be assumed that they master technology as expected in higher education. By drawing on Luhmann's communication theory the educational consequences of the students' media use in teaching and in independent study work is discussed. 
Keywords: Media, communication, higher education, student-activating teaching, educational framework.

\section{Introduction}

"It has been great to be able to relax a bit. I feel I don't have to make such an effort [...] I mean it's [the video] much easier to follow than someone who is explaining [lecturer]".

The above statement shows how one undergraduate student describes his experience of the lecturer's use of video as an opportunity to relax. The lecturer's intention in using the video clip was to generate discussion and invite students to take part in teaching. This statement illustrates what has often been described as a tension between how students choose to use technology in education and the use made of technology by lecturers (Moll, Linder \& Nielsen, 2015; Selwyn, 2016). Along with similar statements, the above student's remark has made us wonder whether attempts to facilitate student-activating teaching by using digital technology really would result in increased activity, such as critically assessing academic sources, collaborating, producing and sharing digital content, participating in dialogues, to mention a few.

The Norwegian Educational Quality Reform in Higher Education (St.meld. no. 27, 20002001) places emphasis on student-activating teaching and the increased use of digital technology as a means to promote learning and teaching quality (Krumsvik, 2016, p. 321). The reform draws on international trends promoting active teaching as pedagogical strategy to engage students in their learning process (Fischer \& Hänze, 2019; Prince, 2004). In a study conducted by the Norway Open University ${ }^{1}$, it is argued that students want teaching that involves the active participation of students, and with the use of technology with which they are already familiar - but that it must be used differently from the way teachers use it (Ørnes, Gaard, Refsnes, Kristiansen \& Wilhelmsen, 2015). Wittek (2015) summarises the results ten years after the Reform, noting, inter alia, that the completion of studies are largely unchanged despite the fact that many teachers have been working hard to create activating teaching including the use of digital technology. As a result of decades of testing different forms of digital technology in education, we also know that technology use does not necessarily result in students being more diligent (Moll et. al., 2015). There are a number of prerequisites, such as competent professionals, didactic facilitation and technical support (Krumsvik, 2016). It is also important that students are adequately prepared and actively participate - a prerequisite that is often disregarded

\footnotetext{
${ }^{1}$ Now known as the Norwegian Agency for International Cooperation and Quality Enhancement in Higher Education: https://diku.no/en
} 
(Tønnessen, 2016).

There is a widespread assumption that today's young students who have grown up with digital technology have effortlessly become competent in technology in all arenas (Moll et al., 2015). From a professional point of view, the claim that young people as a homogeneous group can be described as digitally native or, digitally competent, is rejected and it has been pointed out that there are individual significant differences as far as the use of technology is concerned (Nordkvelle \& Fritze, 2015; Livingstone, 2012; Buckingham, 2006).

We have investigated what media practices third-year students on a bachelor's programme consider as relevant and important and how their use and experiences corresponded with the media use for academic purposes in lectures. We have also investigated which aspects of their social media use were related to their academic interests and needs. Within the context of these issues this article is based on the following research questions:

- How did students relate to teachers' arrangements for media use in lectures and seminars?

- What do the statistics tell us about the way students use the learning platform?

- How and for what purposes did students use social media and online resources in teaching and in independent study work?

The article is based on results from group interviews with students, a survey, and information from activity logs in the study's learning platform. As researchers and teachers on the bachelor course in Media Education we have experience with students' media use.

The discussion of the results draws on perspectives from Luhmans' (2000) communication theory. Our intention is to explore how students understand the current framework in higher education and why they choose to be part of the communication within a teaching framework. The terms "media" and "technology" are used interchangeably. Although the terms analogue and digital are used, in tandem, our chief concern has been digital technology (Tønnessen, 2016, p. 240). The article contributes to a growing research trend that examines young people's perspectives on their own media practices (Bjørgen \& Erstad, 2015; Burnett, 2015).

\section{Research on students' media use in higher education}

Several studies show that students want and expect that the technology they are familiar with from their leisure time is integrated to a greater extent into learning activities, such as reading and writing texts and critically assessing sources (Buckingham, 2006; Krumsvik, 2016). According to a survey carried out by the Norway Open University almost all 
students prefer to use non-institutional technology when communicating or researching subject material rather than the technology offered by the teaching institution (Ørnes et al., 2015, pp. 74-75). Students state that they use Google more often to search for subject matter, rather than Wikipedia or databases available in the institution's library. Similar results can be found in Drange and Birkeland (2016) in their study of how students enrolled in Norwegian teacher training education use media when studying (p. 63). Further, Drange and Birkeland show that students use different strategies to work with teaching materials but common to these strategies is that they are not practiced digitally.

According to Tømte and Olsen (2013) students use social media rather than the institution's email service to contact each other (p. 45). The research literature documents how students mainly use Facebook for entertainment as well as to cultivate their own identity and friendships. They set up Facebook groups where they organise colloquium groups and help each other with independent study work. Students experience Facebook as a private sphere, a "free space" from teachers (Adalberon \& Säljö, 2015; Moll et al., 2015).

Many teachers use Facebook to connect with students, as they often find that students do not visit the learning system or use the email system available at the institution (Tømte \& Olsen, 2013). Moll, Linder and Nielsen (2015) argue that it is highly desirable that teacher educators teach students to appreciate the learning potential offered by online knowledge networks and how exactly students can broaden their academic perspective. In contrast, Selwyn (2009, p. 173) argues that teachers should avoid Facebook, thus allowing students to explore their own role as students unhindered. However, Tønnessen (2016, p. 246) points out that some students take on a mediator role, where they mediate questions between the teacher and students from private Facebook groups.

Moll, Linder and Nielsen (2015, p. 10) argue that students' media practices show that they are most concerned with fast and effective, albeit superficial, solutions to academic challenges. Tømte and Olsen (2013, p. 42) highlight a similar trend by showing how students often share written work among themselves instead of choosing strategies that promote genuine collaboration. Further, Drange and Birkeland (2016) shows that many students prefer to be consumers rather than active content producers when using social media.

\section{Theoretical considerations}

In our investigation of how teachers and students communicate via media we make reference to Luhmann's (2002) understanding of communication, including how communication ensures the maintenance of the (teaching) system. In line with this approach, on-campus teaching - typically lectures and seminars - as well as online teaching and independent study work are seen as interaction systems where different frameworks 
and inclusion and exclusion mechanisms maintain the teaching system.

In the communication theory the transfer metaphor is often used. However, Luhmann rejects the transfer metaphor and disagrees with the premise that the uniformity of a transmitted information between a sender and a recipient is guaranteed through the content quality of the information. Thus, communication is understood as a "chain of selections", or series of choices: the unity of information, communication and understanding (Luhmann, 2000, p. 182). At least two people are required for communication to take place. Luhmann (2002, p. 142) understands teaching as an intentional form of communication, the goal of which is to bring about change within the students. In teaching, other temporary systems may also come into play, but the aim of most of these systems are often without an intentional goal of creating learning. These may take the form of exchanges on social media with a private and social goal for communication. Learning occurs mainly through "interruption" from the social environment, which means that support for learning must be communicative, whether technology is used or not (Rasmussen, 1997, p. 137).

According to Luhmann, there are ways to define types of communication where every situation is coded, and we communicate through codes, which provide the communication with a specific focus. Thus, the complexity of the situation can be limited and regulated (Luhmann, 2000, p. 202). There are also specific codes and sets of frameworks for different types of teaching. For example, it is expected that the lecture, with its conventions on a relatively monologic mode of communication, can be immediately understood as a lecture by the students (Fritze, 2005). The specific communication codes create a framework and a common focus. In an educational setting we interact differently with each other and with media from the way we interact in non-academic or informal settings, for example at home with our family (Burnett, 2015, p. 200).

Since the media preferences of students and teachers differ, these codes sometimes become blurred when we use different technologies in traditional higher education lectures. This issue is related to another important starting point in this study, namely that individual interpretations are also framed by, and mediated through, the technology used. Digital technologies have an impact on both the activities they become part of and how we think and talk about the activities in question; what we need to learn, what technologies can be used in given situations and by whom (Säljö, 2010). In this article, digital competence means taking into consideration the student's expectations of how to use technology for specific activities and contexts (Lankshear \& Knobel, 2006).

Thus, to ensure that communication is secure and predictable, it is perhaps necessary to create clear references to established communication codes (Bolter \& Grusin, 2001). However, a more corrective framework or inclusion and exclusion mechanisms may also be necessary to create focus and maintain communication in teaching communication. A 
key issue in systems theory is how to maintain such a system. According to Luhmann (2000), it is important for the maintenance of educational systems that communication consists of teaching, rather than other forms of communication. At the same time, the ability to observe each other's "face" or communicative actions, irrespective of the teaching takes place face-to-face or online, is essential for gaining understanding of the ongoing communication and thus maintaining the communication system (Luhmann, 2000).

\section{Methodology}

The article is based on several data sources collected over a period of about four months. Data consists of qualitative group interviews, activity logs in the learning platform and a survey. The examples presented are mainly based on qualitative interview data. We used a qualitative approach to increase our understanding of the articulated experiences and perceptions of a sample of Norwegian students. We have employed a "participatory research design" which implies that we engaged our students as participators in developing the research design, research questions, data collection, and discussing the results (Noffke \& Somekh 2005; Heath, Hindmarsh \& Luff 2010).

In the learning platform Fronter we had access to statistics concerning the extent and duration of student logins during the semester. In this context, it was interesting to note the extent to which the students used the information published and whether they used the information before or after teaching sessions. We have not identified individual traffic on the learning platform, but have followed the overall traffic as a group.

The Kahoot-based survey was conducted in conjunction with a social media lecture where we asked students about their use of social media at home and during lectures and seminars, for instance: How often do you use social media in the presence of friends? How often do you use social media during teaching? How often do you think your fellow students use social media during teaching? 61 out of $82(\mathrm{~N})$ students participated in the lecture where the survey was conducted. 51 of these participated in the survey (72\%).

We conducted five group interviews with two to four students in each group. A total of 13 students participated; eight male and five female students, all between 22 and 25 years of age. The students volunteered to take part. We suggest that the sample is representative of the course group as a whole as well as of undergraduate students on the local campus.

Our aim has been to capture a wide range of experiences related to what characterised the student's media use for academic purposes, and to consider this in relation to teachers' arrangements. We developed a relatively open and semi-structured interview guide including key issues regarding the reasons for using online resources and social media in lectures and in teaching and in independent study work, as described by Moll et al. (2015), Selwyn (2009; 2016), Tønnessen (2016) and Ørnes et al. (2015). In line with the expected 
learning outcome in the subject Media Education, we encouraged the students to reflect on their experiences with media from lectures and in their independent study work; how and why they engaged with different media in order to communicate, collaborate, seek information. We also invited them to reflect on their experience with the learning platform Fronter. Finally, we encouraged them to elaborate on their experiences of media use for academic purposes in lectures and seminars, focusing on what engaged or distracted them, with a particular focus on lecturers' use of video clips.

All group interviews took place at the local campus. Each interview ranged from $40-60$ minutes in duration and was recorded and transcribed. Based on a thematic analysis approach (Bernard \& Ryan, 2010), we aimed to obtain descriptions expressing students' attitudes to media in a variety of educational settings. Both authors conducted close reading of the interviews to gain an overall understanding of themes and the main issues mentioned in the interviews. During the coding process, we used different colour labels to highlight the main descriptions in which the true experience was present as well as patterns and variations in students' articulated experience. These descriptions were analysed according to key themes in the interview guide, as well as new themes arising as a result of engaging with the material. We discussed the relationship between key themes and sub-themes comprising the main themes on a continual basis. Based on the analysis of the interviews, and on impressions gained from activity logs in the learning platform and from the survey, we identified the following main themes:

- $\quad$ students' thoughts on teachers' arrangements for media use in lectures and seminars

- statistics on students' use of the learning platform

- students' thoughts on using social media and online resources in teaching and in independent study work.

All interviews have been translated from Norwegian into English by the authors. In the interests of anonymity, students' descriptions were partially edited when presenting the results in order to clarify the meaning and content specified in the categories (Kvale, Brinkmann, Anderssen \& Rygge, 2015, p. 212). The study is conducted in accordance with the ethical guidelines of the Norwegian Data Protection Services.

This is a small-scale study that has some limitations, such as the difficulty of applying results directly to other situations. Since both authors were academically and administratively responsible during data collection this might have had a positive effect on the recruitment, the development of research design, and the interview guide as well as the interviews and the interpretation. It might also have influenced students' answers and our interpretations. We could supplement the analyses with reflections on didactic organisation. However, we have tried to gain benefit from our knowledge of the students and the bachelor's course by reflecting on our assumptions. Our findings are supported in 
similar studies of media use in higher education (Selwyn, 2016; Tønnessen et al., 2016).

\section{Presentation of the subject of study}

This study seeks to create awareness among students about their own media use. Thus, we suggest that participation in this study may prompt further reflection. The subject that forms the basis for this investigation is a full-time course in Media Education and takes place in the third year of a bachelor's programme in Education. 82 students were enrolled on the course, which is organized into seven thematic sessions over two days during a period of about three months. There are three work requirements on the course: one individual assignment and two based on group work. The final part of the course consists of a portfolio examination.

As far as the curriculum is concerned, students will gain insight into three areas of Media Education; media socialization, teaching about media and teaching with media. The following activities are central: media analysis, didactic analysis, critical debate on media in society and the production of a digital story.

Students are expected to use a number of media, the learning platform, in particular, to distribute practical information to students about teaching, work requirements and exams. Learning materials are available online before and after lectures and seminars, and the students submit and receive feedback on work requirements. Students are expected to keep up to date on any information posted online.

Students use tablets and/or PCs and mobile phones for a number of activities, including note-taking, the production of digital narratives, analysing television programmes, and to document (camera) museum visits. In addition, mobile phones are used on an ongoing basis to answer quizzes and surveys in Kahoot where we typically test students' attitudes towards media and ask about their own media use. However, we discouraged them from using mobile phones during lessons and seminars if it is not for academic use.

During lectures and academic seminars, teachers make extensive use of YouTube videos or other audiovisual material to illustrate the syllabus and as a starting point for discussions. "Polls" via Kahoot is also used as a background for discussions. The teachers also often visit the learning platform during lectures to show which teaching materials are posted and where this can be found. In addition, pages with practical content are displayed, for example assignments and exam preparation. 


\section{Students' thoughts on teachers' arrangements for media use in lectures and seminars}

We have grouped the presentation of the results from the empirical study into the core themes presented above. In the interviews, we asked the students about their use of tablets, PCs and mobile phones during lectures and seminars. The majority said they used pen and paper for taking notes. Everyone said they used their mobile phones to participate in the Kahoot survey. However, several students explained that, in common with other students, they used mobile phones, PCs and tablets for non-academic purposes, such as watching YouTube videos and Television, or communicating via social media.

The Kahoot survey gave us initial insight into how many students used media during lectures and seminars for non-academic activities. When asked how often they visited social media during lectures and seminars, $72 \%$ of students $(\mathrm{N}=82)$ responded that they visited social media during all lectures and seminars, while $12 \%$ visited them a couple of times a week. $9 \%$ responded that they rarely used social media during lectures and seminars, while $7 \%$ said that they never used media in non-academic activities. When we asked them how many of their fellow students used social media during lectures and seminars, the number was somewhat higher.

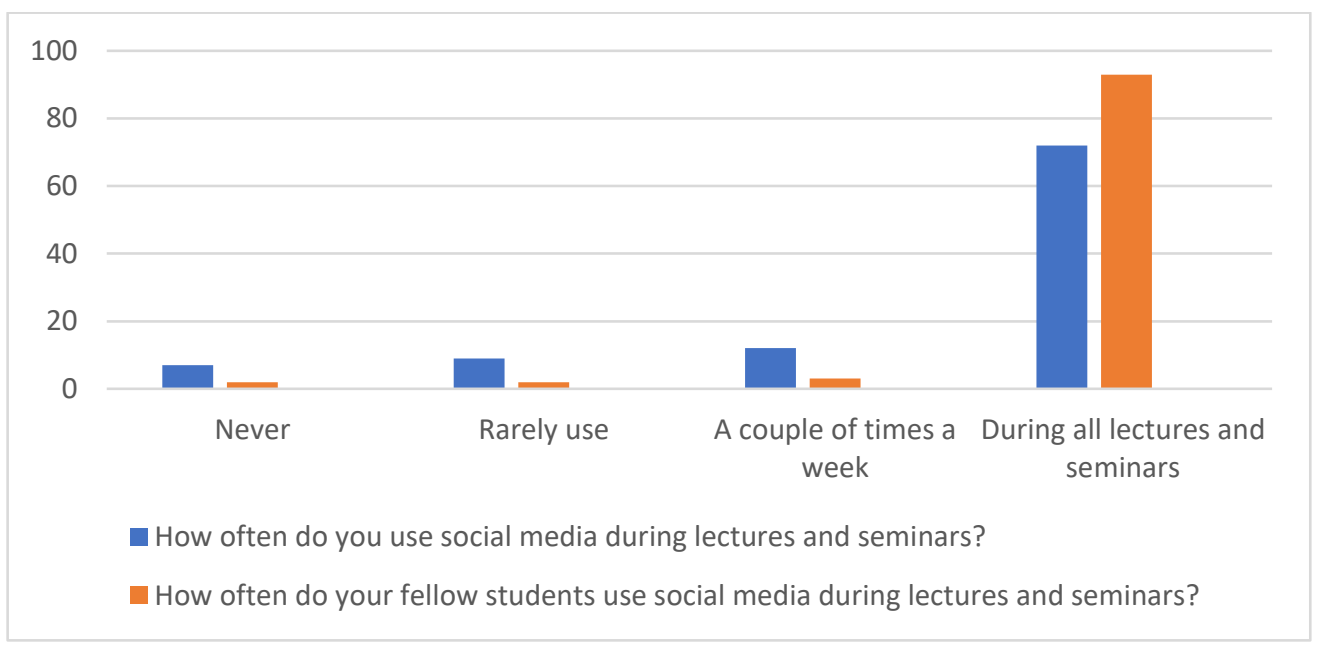

Figure 1. Students' use of social media during lectures and seminars

Figure 1 shows that as many as 93\% reported that they noticed fellow students using social media during all lectures and seminars. Only $2 \%$ reported that fellow students rarely or never used social media during lectures.

Since we often show video clips in lectures to create engagement and variety, we asked the students how they experienced this practice. They claimed that video could be both engaging and distracting: 
It's interesting to have a different perspective of a particular problem. But sometimes it's a bit much. The lights are turned on and off and sometimes there are technical problems, which we are all very familiar with [...] it's easy to just switch off. I lose interest and switch off immediately if there is a hassle with the sound (female student).

Her fellow students agreed with this statement. When we wasted too much time on the technology, switched between movies or turned the lights on and off the result was disruption. The students described such episodes as "an unwelcome interruption", they "lost concentration" and became "disconnected" from the lecture.

Some students remarked that watching a video on YouTube was more relaxing than listening to the teachers. However, a video could still help to drive the message home. One male student explained how he shifted his focus when he watched video:

[...] so that's what you associate with YouTube. When you watch movies you usually relax more. I don't know why but the message sinks in better when it's in movie format [...] you're more used to this format. I've spent more time on YouTube than in lectures. It's just a matter of what you're used to.

It is clear from the quotation presented in the Introduction that students consider the use of video clips in a different way from that intended by the lecturer, namely to prompt action. Whereas the students were relaxed and did not feel they had to pay attention to the lecturer, the teacher's intention was to prompt students to reflect and encourage an atmosphere for reflection and discussion.

Several students said they preferred lectures that were related to the syllabus and with specific explanations on how to understand it, rather than lectures with an element of activating elements, such as discussion of theoretical points based on video clips. One male student described the way he received reading instructions as follows:

[...] I miss the more concrete instructions: 'you can find such and such in this book and such and such in that book' [...] then you have a better idea [...] I really can't tell which of the three books to use.

His fellow students agreed. When we asked whether the reading list we had drawn up for each lecture was sufficient the same female student responded as follows:

[...] but we're too lazy to actually read them. It might be OK if they were put in a PowerPoint presentation where you explain what it's about and where you could find it in the books. I mean, it shouldn't be that difficult to pick up that book.

\section{Statistics on student use of the learning platform}

From the learning platform statistics, we gained an overview of the students' use of 
learning resources and at what time these were used. We noted that as few as $38 \%$ of students visited the learning platform before lectures. The statistics further showed that only half of the students visited all seven pages of learning resources, and about $10 \%$ visited the learning platform for the first time just before handing in the portfolio.

As part of the seminar work, students produced summaries of the syllabus literature and posted these in the learning platform. It was evident from the statistics that less than $10 \%$ visited all seven themes with learning resources. While only a few students were interested in reading the written work of their fellow students, all 82 students read feedback from teachers on work requirements.

\section{Students' thoughts on using social media and online resources in teaching and in independent study work}

When asked what was perceived as other relevant online resources, several students stated that Google and Wikipedia were suitable for "an initial overview of things", such as a topic or an academic term.

If some concepts are difficult to understand, I may google to find a definition so I can get a better idea of what it means. Or I ask the girls I collaborate with [...] on Snapchat or messenger, but if it's something more complex we call each other or meet. But usually we send each other a Snap like this: 'I didn't understand this. What about you?' But if we don't find anything on google, I send an email to the supervisor and ask for help (female student).

In addition to Google and Wikipedia, several websites were mentioned, such as The Norwegian Encyclopedia, the Norwegian Directorate of Education and Training and the university college library.

Students said they used Facebook, Messenger and Snapchat to organise colloquium groups to discuss assignments and to support and encourage each other while studying: "I use Face mostly to organise the group, not for discussions".

They used Google Docs to collaborate on tasks. Several students had thoughts as to how they could combine different technologies, such as Google and Messenger:

We exchange ideas in there [...] then it's great to use Messenger: 'I've changed it. Take a look'. Instead of checking changes in the document you can go straight to the paragraph, and then you just copy and paste it into the word document (female student).

The student describes how her colloquium group used Messenger to notify other students 
when they made changes to their texts. They gained a better overview of the texts. They were used to sharing the group work between them, and before submitting it, an "editor" compiled the entire text. They perceived written communication as challenging since it took "longer than expected". They preferred to meet face-to-face rather than through technology.

\section{Discussion}

\section{Teachers' use of technology create disruptions and disconnections}

In this bachelor's course in Media Education we use media to exemplify theory, i. e. YouTube video clips or Kahoot quizzes and polls because we believe that variety and redundancy in teaching can increase learning opportunities. However, we note that students disconnect from teaching communication when technical problems arise. According to Luhmann (2000), such disruptions can also jeopardise the maintenance of the communication system, and it is therefore important that disruptions are kept to a minimum when teaching. This is an inherent disadvantage when we use technology. Hence, our use of media does not only have positive educational effects. What is evident from the material is that technical problems can have an unexpectedly negative effect on students' participation in teaching communication and hence, learning opportunities.

While teachers expect increased engagement when launching a YouTube video, students describe how they sit still and no longer need to "pretend" to pay attention. This shows that students are entirely aware of established frameworks for a lecture, including what is expected, what counts and what is important (Burnett, 2015). Such descriptions, along with first-hand accounts of how they experience disconnection and rhythm interruptions when teachers tinker fruitlessly with technical devices, can be interpreted as negotiating frameworks. Our findings are supported by Selwyn (2016), who documents that students consider interruptions to be loss of valuable time, as well as attending lectures as a futile exercise: "Students saw these disruptions as 'lost precious time' (...), 'a hindrance to productivity' (...), and contributing to a sense of there being 'no point in attending lectures'(...)" (p. 1012). The desire to negotiate frameworks is perhaps reflected in the students' stated wishes for time to be spent more efficiently on their independent study work, teaching and in the organization of academic resources. In common with our findings, Tønnessen's (2016) contribution of the study habits of trainee teachers shows that they want to streamline both teaching and work requirements and exam work.

\section{Are our students out of reach?}

Despite our efforts to facilitate student-activating teaching by including a diverse range of digital devices, our survey showed that $72 \%$ of the students $(\mathrm{N}=82)$ visited social media for non-academic purposes during all lectures and seminars. $93 \%$ said that the other students 
were using social media for non-academic activities. The numbers indicate that the use of non-academic media creates academic disconnections for the media user while also creating disruption for the other students. Our survey indicates that when students choose to use social media during a teaching session, they switch off from the learning communication and enter a 'private' communication system (Fritze, Haugsbakk \& Nordkvelle, 2017; Luhmann, 2000). Unless one believes in multitasking, it means that students are excluding the intended teaching content in question. This also means that teachers must expect that as many as three quarters of the students are out of range of communication for a shorter or longer period of lecture time.

The material contains detailed descriptions of how the students switch off from the teaching communication - typically through social media. It then becomes difficult for the teacher and students to observe each other's understanding of the ongoing communication. Further, the communicators do not have the chance to make a correction in understanding to the class as a whole, and it becomes harder for the teacher to adapt to the students' needs. There is much in the findings that provides a basis for claiming that the teacher's communication may come across as no more than a monologue (Fritze, 2003).

Student disconnection can also be interpreted by other students as a sign that the teacher and/or the content is boring or too difficult, thereby creating a negative collective understanding (Luhmann, 2000). If the teacher experiences the disconnection as a sign of irrelevant or excessively challenging content, she/he can try to make contact by providing examples or prompting discussions or trying to make direct contact with those students who are disengaged.

However, it should not be forgotten that an important "message" about the quality of teaching and/or about more structural problems in higher education can be seen in the way students in this study orient themselves. In many higher education institutes attending lectures and seminars is compulsory, because participation is considered important for learning. At the same time, many students work full- or part-time alongside their studies. Given our findings of a massive disconnect from teaching communication via digital technology, one gets the impression that student' presence is about being registered in our system. Compulsory attendance in lectures and seminars can be interpreted as a distraction to-students in a more fundamental way. Just how students in this study act can therefore also be understood as an expression of a desire to renegotiate the framework of traditional teaching methods (Krumsvik, 2016).

\section{Students' choices - consumers or active content producers?}

A surprising finding is the students' desire for teacher-centered lectures where the syllabus and content is reproduced rather than discussed and which adds different theoretical perspectives. In the more debating kind of lectures, we often use video examples to 
encourage students to participate, including a discussion of dilemmas and consequences of theoretical choices. In common with the study by Moll et al. (2015), which shows that students tend to seek quick and effective solutions, our material shows that students want more syllabus-related lectures. We suggest that this can be interpreted as an expression of a need to streamline independent study work. From a communication perspective, the students' desires may also reflect their wish to be consumers of education - rather than active content producers based on the teaching dialogue. Drange and Birkeland (2016) have documented similar behaviour in their study of the use made by teacher students' of social media, while the survey of the Norway Open University (Ørnes et al., 2015) showed that students want more student activating-teaching.

There is, however, one area in which students' media use is in line with the intended media use for academic purposes. They generally read our feedback on their written work requirements in the learning platform. This confirms our view that students are committed to improving efficiency, and that independent study work of especial relevance to exams is often prioritised (Moll et.al, 2015). Tønnessen (2016, p. 240) sees a similar trend towards streamlining independent study work, where strategic reading rather than systematically working through the syllabus is used to pinpoint relevant material for answering work requirements. The exams in this bachelor's course take the form of portfolio exams and include an opportunity to improve work requirements. In their preparations, students always read our feedback. Although there is limited interest in the summaries produced by the students themselves and posted on the learning platform, it is still evident that strategic study work with an exclusive emphasis on essential information takes precedence.

\section{Social media as a response to challenging institutional systems?}

A common denominator in our material is the students' descriptions of how they prefer social media rather than the university college's solutions when working with the syllabus on their own (Tømte \& Olsen, 2013). In particular, our learning platform was regarded as complicated (Drange \& Birkeland, 2016, p. 61; Selwyn, 2016). The students said they visited the platform only occasionally, mostly to comply with the teacher's expectations.

Our findings show that Facebook, Messenger and Google Docs are considered relevant for academic purposes, such as monitoring and managing study-related work, such as sharing administrative information, and how to collaborate and participate in colloquium groups. The findings are in line with other studies (Adalberon \& Säljö, 2015; Moll et. al, 2015; Selwyn, 2009). Our results, however, are not corroborated by the findings from Norway Open University, which show that students want the educational institutions to use media they are most familiar with from their spare time to be used in student-activating teaching (Ørnes et al., 2015). This can be explained by the fact that we only integrate social media into teaching to a limited extent, and therefore our students do not expect to use it. The limited use can also be understood from the fact that students do not want to give teachers insight into their private sphere on social media (Selwyn, 2016). From the material it is 
evident that the students prefer to use "private" media for communication related to their homework, hence, there is a transition between different communication systems (Luhmann, 2000). When the teacher is not invited into the system, he or she will not be able to observe the students' communication. For the students this arrangement creates efficiency but can also interfere with the teaching system due to the references contained in the medium itself. Based on these findings we suggest that the communication situation does not alone govern how we communicate; it is also important to take into account the media experiences that students bring into the learning environment (Bjørgen \& Erstad, 2015; Bolter \& Grusin, 2001; Säljö, 2010).

The students' descriptions of social media as relevant to information exchange and collaboration testifies to the fact that they think efficacy is of paramount importance. They seek help in tried and tested ways from their closest circle of friends on Facebook, or with fellow students on campus (Moll et al., 2015; Selwyn, 2009). They search for easily accessible sources, such as Google and Wiki, because they find the institutions' databases difficult to access. In co-writing, the work is distributed based on the method: along the lines of "you do this and I'll do that" (Tømte \& Olsen, 2013, p. 42). It is obvious that the students interpret independent study work and teaching in an instrumental manner. Moll et al. (2015) also document this, acknowledging the risk that such an approach results in quick and superficial solutions to academic challenges.

\section{Conclusions}

This article has focused on what media practices third-year students on a bachelor's course consider as relevant and how their use and experiences corresponded with media use for academic purposes in lectures set by teachers. We have also investigated which aspects of their social media use were related to their academic interests and needs. Like many other studies, our study shows that tensions exist between how lecturers prepare for media use, and what students perceive as relevant to a course of study (Moll et al., 2015; Selwyn, 2016; Tønnessen et al., 2016). To sum up, we suggest that the examples discussed above raise a number of important questions that should be considered by educators and researchers when reviewing attempts to facilitate student-activating teaching by using digital technology.

The students considered the institution's analogue and digital subject resources and learning platform to be of little relevance. Any intentions to encourage learning through the use of technology in teaching seem to be perceived by students as disruptive or superfluous. Conversely, we see that students' use of social media during lectures and seminars disconnects them from teaching. They enter a non-academic zone, creating disruptions for teachers and fellow students alike (Selwyn, 2016, p. 1012). However, Selwyn also reminds us that students' experiences of technology as problematic and disruptive should be taken as seriously as their experiences of technology as positive and 
unproblematic (p. 1016).

We have argued that both students and lecturers need to be more aware of the importance of how individual interpretations of media practices are shaped by contextual procedures and frameworks (Selwyn, 2009). On the one hand, it can be argued that students ought to familiarise themselves with the institution's technical solutions, learning platforms and academic databases. On the other hand, educational institutions and producers of new learning technologies must take into account students' experiences, skills and expectations from social media use. There is a great deal in the material to suggest that social media like Facebook and Messenger, together with online resources including Google and Wikipedia, are perceived as relevant for organising academic work and for social exchanges and reassurance. However, it is all too easy to perceive students as a digitally competent and homogeneous mass simply because they have grown up with digital technology. Our findings document that the students find databases of the institution in question and the respective learning platform difficult to access. In other words, we cannot take for granted that students master what is required in an academic setting. If the tension between access to digital resources, students and lecturers' expectations, and real digital practices becomes too great, lecturers may lose interest in developing sophisticated digital learning arrangements (Krumsvik, 2016, p. 322).

The findings of this study also indicate that the students are engaged in negotiating an acceptable framework for media use in lectures, seminars and their independent study work. They have provided feedback on what they consider to be challenging regarding the institution's technological solutions, especially related to learning platforms. In sum, this can be interpreted as input into negotiations on how we might understand the role of the modern student. Students often have to work full- or part-time and are unable to comply with the demands of a traditional university timetable. Although student-activating teaching, somewhat discouragingly, has resulted in a slackening of attention and nonacademic activities, it can be seen in light of the modern student's desire for efficiency and streamlining. Our findings point towards a scenario where modern students do not necessarily want more technology and student activating teaching. On the contrary, it is evident that the use of technology in teaching must take into account students' need for efficiency and learning strategies, as well as their previous experiences, competences, and preferences in using social media and online resources. Research into how the so-called modern students relate to learning and technology use in higher education is still in its infancy.

\section{References}

Adalberon, E. \& Säljö, R. (2015). Informal use of social media in higher education. A case study of Facebook groups. Nordic Journal of Digital Literacy, 12(4), 114-128. https://doi.org/10.18261/issn.1891-943x-2017-04-02 
Bjørgen, A.M. \& Erstad, O. (2015). The connected child: tracing digital literacy from school to leisure. Pedagogies: An International Journal, 10(2), 113-127. https://doi.org/10.1080/1554480X.2014.977290

Bolter, J.D. \& Grusin, R. (2001). Remediation: understanding new media. Cambridge, Mass: MIT Press.

Buckingham, D. (2006). Is there a digital generation? In D. Buckingham (Ed.), Digital generations: Children, young people, and new media (pp. 1-14). Mahwah, N.J.: Lawrence Erlbaum.

Burnett, C. (2015). Investigating children's interactions around digital texts in classrooms: how are these framed and what counts? Education, 3-13, 43(2), 197-208. https://doi.org/10.1080/03004279.2013.800576

Drange, E-M.D. \& Birkeland, R. (2016). Digitalt innfødte eller digitalt velfødde? En studie av lærerstudenters tekstpraksis generelt og i studiesituasjonen. I E. S. Tønnessen, N.R. Birkeland, E-M.D. Drange, G. Kvåle, G-R. Rambø, \& M. Vollan (red.). Hva gjør lærerstudenter når de studerer? Lesing, skriving og multimodale tekster i norsk grunnskolelærerutdanning. Oslo: Universitetsforlaget, 53-70.

Fischer, E. \& Hänze, M. (2019). Back from "guide on the side" to "sage on the stage"? Effects of teacher-guided and student-activating teaching methods on student learning in higher education. International Journal of Education Research, 95, 26 25. https://doi.org/10.1016/i.ijer.2019.03.001

Fritze, Y. (2003). Dialogiske monologer og monologiske dialoger. I Y. Fritze, G. Haugsbakk \& Y. T. Nordkvelle (red.). Dialog og nærhet. IKT og undervisning. Kristiansand: HøyskoleForlaget.

Fritze, Y. (2005). Mediet gør en forskel. En komparativ undersøgelse af kommunikation $i$ nærundervisning og fjernundervisning. Doktorgradsavhandling, Syddansk Universitet, Odense.

Fritze, Y., Haugsbakk, G. \& Nordkvelle Y.T. (2017). Digitale forstyrrelser i skolen erfaringer med begrensninger av elevers mobilbruk. Norsk pedagogisk tidsskrift, 101(3), 201-212. https://doi.org/10.18261/issn.1504-2987-2017-03-02

Haugsbakk, G., \& Nordkvelle, Y. (2013). Den motvillige teknologen og læringssamfunnet. I P. Arbo, T. Bull \& A. Danielsen (red.), Utdanningssamfunnet og livslang læring. Festskrift til Gunnar Grepperud (pp. 113-138). Oslo: Gyldendal Akademisk.

Heath, C.; Hindmarsh, J. \& Luff, P. (2010): Video in Qualitative research. Analyzing Social Interaction in Everyday Life. London: Sage. https://doi.org/10.4135/9781526435385

Kvale S, Brinkmann S, Anderssen TM, Rygge J. (2015). Det kvalitative forskningsintervju. 3. utg., 2. oppl. ed. Oslo: Gyldendal akademisk. 
Krumsvik, R. J. (2016). Digitale paradoks og undervisningskvalitet: epilog. I R. J. Krumsvik (red.) Digital læring i skole og lærerutdanning (pp. 320 - 327). Oslo: Universitetsforlaget.

Lankshear, C., \& Knobel, M. (2006). New literacies: Everyday practices and classroom learning. Maidenhead: Open University Press.

Livingstone, S. (2012). Critical reflections on the benefits of ICT in education. Oxford Review of Education, 38(1), 9-24. https://doi.org/10.1080/03054985.2011.577938

Luhmann, N. (2000). Sociale systemer - grundrids til en almen teori. København: Hans Reitzels forlag.

Luhmann, N.( 2002): Das Erziehungssystem der Gesellschaft. Frankfurt am Main: Suhrkamp Verlag.

Moll, R, Nielsen, W. \& Linder, C. (2015). Physics students' social media learning behaviors and connectedness. International Journal of Digital Literacy and Digital Competence, 6(2), 16-35. https://doi.org/10.4018/IJDLDC.2015040102

Noffke, S. \& Somekh, B. (2005) Action Research. In B. Somekh \& C. Lewin (Eds.). Research Methods in the Social Sciences (p.89-96). Los Angeles: Sage.

Nordkvelle, Y. T. \& Fritze, Y. (2015). Digitalt innfødte eller bare medialiserte? I Y. Fritze, G. Haugsbakk, \& Y. T. Nordkvelle (red.). Mediepedagogiske perspektiver. Mediesosialisering, undervisning om og med medier. Oslo: Cappelen Damm Akademisk, 67-85.

Prince, M. (2004). Does active learning work? A review of the research. Journal of Engineering Education, 93(3), 223-31. https://doi.org/10.1002/i.21689830.2004.tboo809.x

Rasmussen, J. (1997): Socialisering og læring i det refleksivt moderne. København: Unge Pædagoger.

Säljö, R. (2010). Digital tools and challenges to institutional traditions of learning: Technologies, social memory and the performative nature of learning. Journal of Computer Assisted Learning, 26(1), 53-64. https://doi.org/10.1111/j.13652729.2009.00341.X

Selwyn, N. (2009) Faceworking: exploring students' education-related use of Facebook. Learning, Media and Technology, 34(2), 157-174. https://doi.org/10.1080/17439880902923622

Selwyn, N. (2016). Digital downsides: exploring university students' negative engagements with digital technology. Teaching in Higher Education, 21(8), 1006-1021. https://doi.org/10.1080/13562517.2016.1213229 
St.meld. no. 27, 2000-2001 [(White paper]. Gjør din plikt - krev din rett. Kvalitetsreform av hoyere utdanning. Kirke-, utdannings- og forskningsdepartementet. https://www.regjeringen.no/no/dokumenter/stmeld-nr-27-2000-2001-/id194247/

Tømte, C.E. \& Olsen, D.S. (2013). IKT og læring i høyere utdanning: kvalitativ undersøkelse om hvordan IKT påvirker i høyere utdanning. Oslo: NIFU.

Tønnessen, E.S., (2016). Oppsummering, drøfting og nye utfordringer. I E.S. Tønnessen, N.R. Birkeland, E-M. D. Drange, G. Kvåle, G-R. Rambø, \& M. Vollan (red.). Hva gjør lærerstudenter når de studerer? Lesing, skriving og multimodale tekster i norsk grunnskolelærerutdanning. Oslo: Universitetsforlaget, 240-252. https://doi.org/10.18261/9788215026312-2016-11

Wittek, L. (2015). Ti år etter kvalitetsreformen - ingen økning i studiegjennomføringen. Uniped, 38(3), 160-163. ISSN online:1893-8981.

Ørnes, H., Gaard, H., Refsnes, S. I., Kristiansen, T. og Wilhelmsen, J. (2015). Digital tilstand i høyere utdanning 2014. Norgesuniversitetets IKT-monitor, Norgesuniversitetets skriftserie 1/2011, Tromsø: Norgesuniversitetet. 